ISSN 0258-7122

Bangladesh J. Agril. Res. 39(1): 47-57, March 2014

\title{
AN ECONOMIC SURVEY OF COWPEA (Vigna unguiculata) STORAGE PRACTICES IN KWARA STATE, NIGERIA
}

\author{
FAKAYOdE, B. SEGUN ${ }^{1}$, OMOTESHO, A.OLUBUNMI ${ }^{2}$ \\ AND ADEBAYO, T. ZAINAB ${ }^{3}$
}

\begin{abstract}
Grain cereals are the food security staples of the poor masses around the globe. However, a significant proportion of these crops, especially cowpea are lost during storage. This is more so the case in Africa where postharvest losses due to the absence of efficient storage for cowpea is alarming: between 30-70 percent. This study, therefore, examined the adoption of improved cowpea storage practices/facilities by cowpea farmers and traders in Nigeria, using Kwara State as case study. The study specifically investigated factors affecting cowpea storage practices. For the study, 180 households involved in cowpea storage activities were selected across the study area and interviewed. Data analysis tools were the descriptive statistics and logistic regression tools. The descriptive statistics was employed to analyse the socio-economics and cowpea storage practices of respondents, while the logistic regression tool was used to identify factors affecting respondents' likelihood to adopt popular improved cowpea storage technique 'crib' in the study area. The study results indicate that most of the respondents have not had any form of formal education. The common storage agro-chemicals used by the respondents were actellic liquid, actellic dust, and phostoxin. Crop storage practices identified in the study area were the traditional ones, involving the use of old drums, jute bags, earthen pots, gourds and rhumbus. The improved/modern storage practices identified comprised the use of cribs and a handful patronage of public silos. Logistic regression results showed that the perception of respondents about storage pest as threats to their crops, their household size, and credit availability variables are significant at 5 percent level, implying that these variables determine respondents' likelihood to adopt the crib storage technique for their cowpea. However, the type of education whether formal or informal acquired by the respondents' variable is insignificant and therefore, does not determine respondents' likelihood to adopt the crib storage technique for their crops. Factor identified as constraints to efficient storage practices were inadequate credit facilities, high costs of and poor access to improved storage facilities. The study, therefore, concludes that there is an urgent need for the provision of credit facilities to cowpea farmers and grain traders alike, subsidy on improved storage facilities and ease of access to the improved storage facilities
\end{abstract}

Keywords: Logistic regression, descriptive statistics, threat, likelihood, food security, cereal.

${ }^{1,2 \& 3}$ Department of Agricultural Economics and Farm Management, P.M.B 1515, University of Ilorin, Ilorin, Nigeria. 


\section{Introduction}

The ever widening food demand-supply gap in Nigeria is sequel to the country's increasingly high population growth and the high demand for her low priced food items. However, the average crop yield for most of these food items have been generally low from farmers' fields. Crops yields range between 250-500 $\mathrm{kg} / \mathrm{hectare}$ for maize, rice, millet, and sorghum (Sharma and Nwanze, 1997).

Over the years, successive governments in Nigeria initiated several programmes/schemes aimed at raising the nation's agricultural production. However, several constraints have posed as challenges to these efforts. Nigeria's agriculture is constrained by many problems including those of lack of continuity and irrelevant multiplicity of government programmes/schemes for agriculture, devastating climate change effects of drought, floods and desertification, inadequate resources including land, labour, and capital investment into agriculture and low productivity of these resources, high incidence of pests and diseases, poor and inadequate agricultural technology, scarcity and high cost of improved agricultural inputs, inadequate agricultural finance, lack of appropriate land tenure systems, poor remuneration for farmers' produce with little or no world market demands for their produce, high dependence on unimproved inputs and rudimentary technologies, inadequate agricultural extension, heavy crop losses during harvesting and post-harvest, processing and marketing facilities as well as poor infrastructural development (Akinwumi, 1996: Olayemi, 1988: Olayemi and Akinyosoye, 1989: Njoku,1998: Onyenwaku, 2000: NISER, 2001: Manyong et al,2008). Amongst these problems, an important aspect of the food problem that has long deterred the nations' food security efforts has been that of her poor and inefficient storage facilities for food crops. Despite the numerous advantages of crop storage, damage by storage pest, especially the insect pests are the most important limiting factors to the efficient storage of agricultural products. In some instances, losses up to 30 to 70 percent have been recorded on stored food in the absence of efficient storage pest control measures (Dike, 1994). The severe damage caused by storage pest lowers the quality and quantity of the crop produce, as they eat up portions of the produce leading to losses usually manifested by reduction in weight (Kumar et al.,1996). These pests also contaminate produce with trash and foreign materials. It has been estimated that about 75 percent of problem of food storage is due to insect pests. The total estimated annual loss of grains to insects' pest in Nigeria is about 20 per cent of total production (Ajibola and Daramola, 1998).

Storage pest cause direct and indirect damages to stored agricultural products. Direct damages are in the form of weight loss, loss in grade of grains, lowering of harvests' market value, contamination and damage to storage structures. Indirect damages on crops include heating and moisture migration in silos and other storage structures like the traditional African silo: 'rhumbu' and 
cribs. Other indirect damages include the spreading of moulds and spores throughout the grain mass and monetary expenses in terms of having to purchase pest control chemicals.

Damage and losses to stored grain, especially cowpea by insect pests is very severe. About 4 percent of total annual production of cowpea or about 30,000 tonnes valued over 30 million US dollars is lost annually to the cowpea brunched in Nigeria alone (Caswell, 1980; Singh et al., 1983). The most important storage pest of cowpea is the weevil (Bruchid) called Callosobruchus maculatus. Severe infestation can lead to total grain loss in storage. It is a field-to-store pest; adult beetles lay eggs on pods (in the field) or on seeds (in storage). After hatching, the larvae develop within seeds and eat up the cotyledon, thereby causing extensive damage. Adults emerge from the seeds through characteristic holes made by the larvae. (IITA, 2009). Musa and Adetunji (1999) reported that in Nigeria, consumers shy away from holder grain, especially cowpea. The problem is further aggravated by the simple reason that the storage of cowpea in Nigeria is in the hands of the small-scale peasant farmers who have little knowledge and resources to procure necessary storage facilities and chemicals for pest control.

Cowpeas play a key role in the agriculture and food supply of Nigeria: Nigeria is the largest producer and consumer of cowpeas, accounting for about 45 percent of the world's cowpea production. As of 2004, it was also the world's largest cowpea importer. Nigeria is the largest producer and consumer of cowpeas in the world. In the 1990s, Nigeria accounted for about 45 percent of the world's cowpea production. As of 2004, it was also the world's largest cowpea importer, with annual imports of around 300,000 metric tons from neighbouring countries. Niger was the largest single source of cowpeas imported to Nigeria in the 1990s, with around 260,000 metric tons per year. The major producing countries in Africa are Nigeria, Senegal, and Tanzania (FAO, 2006).

In the light of the foregoing, the current study appraised cowpea farmers and cowpea marketers' adoption of improved cowpea storage facilities/technologies in Nigeria, using Kwara State, as a case study. The study sought to provide answers to the following pertinent research questions:

* What are the different post harvest storage practices available for farmers cowpea in Nigeria?

* What are the attitudes of farmers towards the adoption of improved cowpea storage techniques/facilities?

* Which factors influence farmer's likelihood to adopt and use improved cowpea storage techniques/

/facilities? 
The study's specific objectives were, therefore, to:

* identify the nature of cowpea storage activities in the study area;

* determine costs and returns to cowpea storage in the study area; and

* identify the factors that influence farmers' likelihood to adopt improved cowpea storage facilities/techniques.

The prevention and/or reduction of post harvest food losses are of great benefit to the Nigerian economy. Over the years, post harvest losses anticipated by farmers limited their efforts at increasing food production. Farmers in most instances do not embrace production techniques that can increase their yield. This is because a bountiful harvest may not yield the expected profits since a substantial part of the yield may be lost to spoilage before reaching the market (Ajibola, 1998). The severe damage caused by crop storage pests lowers the quantity and quality of stored grains available for consumption and this in turn affect the market price of the produce.

A study as the current one, therefore, becomes imperative, as it identified factors that influence the adoption of improved cowpea storage facilities in the study area. Such study outcomes could, therefore, proffer suggestions as to ways to improve the quantity and quality of cowpea in Nigeria.

\section{Methodology}

\section{Data sources and collection}

This study was conducted in Kwara State, Nigeria. Kwara State lies between latitudes $7^{0} 45^{!} \mathrm{N}$ and $9^{0} 30^{\prime} \mathrm{N}$ and longitudes $2^{0} 30^{\prime} \mathrm{E}$ and $6^{0} 25^{\prime} \mathrm{E}$. The state covers a total land area of about 332,500 square kilometers and shares boundary with Ondo, Oyo, Osun, Niger, and Kogi states in Nigeria and an international border with the Republic of Benin along its north-western part. The state has two main climatic seasons; the dry and wet seasons. The natural vegetation of the state comprises of the wooded and rain forest savannah. Major land forms in the state are plains, undulating hills, and valleys. The favourable climate and the large expense of land makes the wooded savannah in the state well suited for the cultivation of a wide variety of food crops including cereals like maize and guinea corn. Tubers like yam, potatoes, and cassava, legumes, such as cowpea and bambara nut and vegetables like spinach and Okro (Kwara State Ministry of Information, 2002). The State has a population of about 2.37 million people (NPC, 2006).

\section{Sampling technique adopted}

The target population for this study were the cowpea farmers' households involved in cowpea storage activities in the study area. Given the classification 
of Kwara State into four (4) zones A, B, C, and D by the Kwara State Agricultural Development Project KWADP (1996), a two (2) stage sampling technique was employed to select the farmer households sample for the study. The first stage comprises a random selection of eight (8) villages in the KWADP zones, while the second stage involved the random selection of one hundred and sixty-five households involved in cowpea storage activities across the selected villages.

In arriving at the marketers/traders' households sample, a two stage sampling procedure was also employed. The first stage comprised a purposive selection of Ilorin, the capital city of the study area, Kwara state. Within the state capital, Ilorin are popular markets in the study area. Theses markets include the Ago, Ganmo, Ipata, and Oja-Oba markets (Fakayode et al., 2008). These markets are large markets, those that are patronised daily, except for the Ganmo market which is patronised only at designated days (Periods). In these markets, cowpea wholesalers sell out their commodities to retailers, thereby distributing his commodities to them in batches. The wholesale usually stores their cowpea in warehouses as the need arises before they finally transports the commodity to markets. The second sampling stage for selecting the cowpea traders respondents involved the random selection of fifteen traders households that are involved in cowpea storage activities at the Ago and Oja-Oba markets. All the households were wholesaler traders of cowpea.

In all, a total of 80 households (165 cowpea farmers and 15 cowpea traders) respondents were sampled and interviewed for the study (Table 1)

Table 1. Sample design outlay for the selecting cowpea farmers and cowpea trader households respondents for study.

\begin{tabular}{c|c|c}
\hline ADP Zone & Village/Town & No. of respondents \\
\hline \multirow{2}{*}{ A } & Kanikoko & 15 \\
& Kemanji & 15 \\
& Venra & 15 \\
B & Lafiagi & 15 \\
& Sanbufu & 15 \\
& Edogi & 15 \\
C & Yakuba & 15 \\
& Oke-Oyi & 15 \\
& Ilorin & 15 \\
D & Erin-Ile & 15 \\
& Igosun & 15 \\
& Ipe & 15 \\
Total & 12 & 180 \\
\hline
\end{tabular}

Source: Field Survey (2008) 


\section{Analytical techniques}

The tools of analysis employed for the study are the descriptive statistics and logit model.

\section{Descriptive statistics}

Descriptive statistics, such as frequency, percentages, mode, and median were used to analyse the socio-economic characteristics of respondents and the various post harvest storage activities of respondents.

\section{Statistical Techniques}

The logit model was used to analyse factors influencing the decision of households to use improved storage techniques. Feeder et al. (1985) showed that many models used in adoption studies fail to meet the statistical assumption necessary to validate the conclusions based on the hypothesis tested.

During the study, it was found that the popular modern storage techniques adopted by farmers in the study area is the crib technology. The logit model was therefore, used to investigate factors affecting respondents likelihood to adopt the crib technology in the study area.

Following Kramer (1991); the model is specified as

$$
\underset{1-\operatorname{Prob}(\text { Yes })}{\operatorname{Prob}(\text { Yes })}=\beta_{0}+\beta_{1} X_{1}+\beta_{2} X_{2}+\beta_{3} X_{3}+\beta_{4} X_{4}+\mu_{t}
$$

Where $X_{1}$ is a variable that indicates whether a respondent perceive pests as threats to cowpea storage. This variable was dummied as Yes $=1$ if respondents perceive pests as threats to cowpea storage and 0 if respondents perceives otherwise. $\mathrm{X}_{2}$ is the respondents household size, $\mathrm{X}_{3}$ is the type of education acquired by the respondents, whether formal or informal. This was dummied as informal $=0$ and formal $=1, \mathrm{X}_{4}$ indicates respondents usage of credit access or use which was dummied as 1 if respondent obtained credit and 0 if otherwise, $\mu_{t}$ is the independently distributed random variable with zero mean and Prob (Yes) is the probability that the respondent uses crib to store his cowpea.

\section{Results and Discussion}

The result on the socio-economic profile investigation of the respondents is as presented in Table 2

The size of the respondents' households is important. Those with large households are expected to have access to more family labour for their storage activities. Table 2 shows that over half of the respondents have households that comprised of less than or equal to ten members. The mean household size per 
respondents was found to be 9 persons implying that respondents have large households. This could also imply that most of the respondents can source labour easily from their households.

Table 2. Socio-economic profile of respondents.

\begin{tabular}{|c|c|c|}
\hline Characteristics & Frequency & Percentage \\
\hline \multicolumn{3}{|l|}{ Household Size } \\
\hline $1-5$ & 19 & 10.6 \\
\hline $6-10$ & 106 & 51.9 \\
\hline $11-15$ & 50 & 27.8 \\
\hline$>15$ & 4 & 2.8 \\
\hline Total & 180 & 100.0 \\
\hline Mean & 9 & \\
\hline Co-efficient of variation & 0.10 & \\
\hline \multicolumn{3}{|l|}{ Storage Experience in Years } \\
\hline $1-10$ & 50 & 27.8 \\
\hline $11-20$ & 112 & 62.2 \\
\hline $21-20$ & 18 & 10.0 \\
\hline Total & 180 & 100.0 \\
\hline Mean & 14 & \\
\hline Co-efficient of variation & 0.16 & \\
\hline Educational Status & 72 & 4.0 \\
\hline Non-formal & 51 & 28.3 \\
\hline Primary & 16 & 8.9 \\
\hline Secondary & 22 & 12.3 \\
\hline Adult & 19 & 10.6 \\
\hline Quranic & 180 & 100.0 \\
\hline Total & & \\
\hline \multicolumn{3}{|l|}{ Source of Credit Used } \\
\hline None & 100 & 55.6 \\
\hline Cooperative & 80 & 44.4 \\
\hline Total & 180 & 100.0 \\
\hline
\end{tabular}

Source: Field Survey (2008).

About half of the respondents (62.2\%) have over 10 years of farming experience. However, the mean period of experience was found to be 14 years. The respondents are, therefore, conversant with their own traditional storage practices for cowpea. The result could also indicate that the respondents are well conversant with the postharvest diseases and pest symptoms of cowpea. 
Most of the respondents have not had any form of formal education. Only a few (37.1 percent) have had at least six years of basic/primary school education. None of the respondents had post-secondary education. The other remaining respondents have had either the quaranic or adult education (Table 2). The result on respondents educational status indicates a low level of formal education for respondents. This could be a limiting factor affecting respondents' ability to adopt and use improved storage techniques and facilities introduced to them.

Credit availability and its adequacy enable cowpea farmers and traders alike to adopt improved storage techniques. However, only a handful of the respondents (44.4 percent) were able to obtain and use credit fund sourced from their cooperative societies. All the other respondents used their personal savings to fund their cowpea storage activities. It is important to note, however, that most respondents who were able to obtain credit facilities admitted that they used their loan sum to meet other needs aside the storage of their cowpea.

As regards the storage activities of the respondents, Table 3 presents the nature of storage activities undertaken by respondents in the study area. As shown in the Table, most of the respondents employ family labour to carry out their cowpea storage activities. Only a few rely on hired or family labour. The storage structure/facility used for cowpea is important for any effective storage activity. Table 3 shows that cowpea storage is mostly practiced in stores that were inherited by the respondents. However, about one-third of the respondents (31.7\%) stored their cowpea in rented apartments and rented warehouses. Those respondents who store their produce in rented structures are, therefore, expected to incur extra costs than those storing their crops in inherited apartments. About half of the respondents $(44.6 \%)$ store their crops in bag like sacks. Cowpea storage in crib is also indicated to be common amongst respondents. However, majority of the respondents store their crops in both bags and cribs. After drying the cowpea in the crib, the cowpea is reportedly threshed and its grains is stored in bags and sacks. Modern improved storage for cowpea like those involving the use of silo are reportedly used only by a very few of the respondents (1.7 percent). This is probably so, because silo facilities are expensive and not easily accessible in the study area.

Popular post harvest pest control chemicals used by respondents to store their cowpea include actellic liquid, actellic dust, and the phosphotoxin tablets. More than half of the respondents (54.4\%) used phosphotoxin to store their cowpea most probably because phosphotoxin is cheaper and easy to use compared to the actellic liquid alternative. A few of the respondents (45.6\%) combined actellic dust and actellic liquid to store their crops. 
Table 3. Distribution of respondents based on characteristics of their cowpea storage activities.

\begin{tabular}{l|ll}
\hline Activity & Frequency & Percentage \% \\
\hline Source of Labour & 94 & \\
Family & 86 & 52.2 \\
Family \& Hired & 180 & 46.8 \\
Total & & 100.0 \\
& & \\
Mode of Store Acquisition & 77 & 42.8 \\
Inherited & 57 & 31.7 \\
Rented & 46 & 25.5 \\
Owned & 180 & 100.0 \\
Total & & \\
& & \\
Agrochemical Used & 30 & 16.7 \\
Actellic Dust & 52 & 28.9 \\
Actellic Liquid & 98 & 54.4 \\
Phosphotoxin & 180 & 100.0 \\
Total & & \\
& & \\
Storage Techniques Facility Used & 4 & 2.2 \\
Earthen Pot & 13 & 7.3 \\
Jute Bag & 1 & 0.5 \\
Gourd & 7 & 4.0 \\
Raised Platform & 29 & 16.1 \\
Drum & 21 & 11.7 \\
Rhumbu & 3 & 1.7 \\
Silo & 77 & 44.6 \\
Bag/Sack & 40 & 22.2 \\
Crib & 180 & 100.0 \\
Total & & \\
\hline
\end{tabular}

Source: Field Survey (2008)

The logit regression model was employed to identify those factors affecting respondents' likelihood to use improved technologies/facilities to store their cowpea. However, during the study, the only improved cowpea storage facility used by respondents was reportedly the crib facility. The logit regression tool was, therefore, used to capture factors affecting respondents' likelihood to use the crib facility to store their cowpea. The logit regression result is as presented in Table 4.

From the result in Table 4, only the co-efficient of variables $X_{1}$; respondents' perception of pest as threat to their stored cowpea is not significant even at 10 percent level. The variable, however, has the expected positive apriori sign. All the remaining variable coefficients including that for $\mathrm{X}_{2 \text { : }}$ type of education acquired by respondents (Whether formal or informal), $\mathrm{X}_{3}$ household size of the 
respondents and $\mathrm{X}_{4}$ : credit access/use by respondents is significant at 5 percent level of significance.

Table 4. Logit regression results indicating factors determining respondents likelihood to use crib facility to store their cowpea.

\begin{tabular}{l|c|c|c}
\hline \multicolumn{1}{c|}{ Factor } & $\begin{array}{c}\text { Regression co- } \\
\text { efficient }\end{array}$ & Standard Error & $\mathrm{t}$ - value \\
\hline Threat $\mathrm{X}_{1}$ & 0.01025 & 0.6501 & 0.15770 \\
Type of Education $\mathrm{X}_{2}$ & -1.94819 & 0.34882 & -5.58514 \\
Household size $\mathrm{X}_{3}$ & -0.71885 & 0.33655 & -2.13593 \\
Credit Access $\mathrm{X}_{4}$ & -0.50042 & 0.23159 & -2.16075 \\
\hline $\begin{array}{l}\text { Degree of Freedom } \\
\text { Standard Error of }\end{array}$ & & 175 & \\
Regression & & 0.40868 & \\
\hline
\end{tabular}

Source: Field Survey (2008)

The education variable co-efficient does not possess the expected apriori sign. It is negatively signed. This is probably so, because majority of the respondents were of limited formal educational status. Most of them were reportedly to have only acquired the basic six years of primary education. At such elementary levels, they are seldom introduced to practical agriculture talk less of crop storage techniques. Both the credit access and household size of respondent variable co-efficients have expected apriori signs. On the other hand, the household size is negative.

\section{Summary and Conclusion}

In conclusion, this study examined postharvest storage practices for the important cowpea staple in Nigeria using Kwara State as a case study. The study has shown that farmers and traders who are involved in cowpea storage activities have the zeal to use, better improved storage techniques and facilities to store their cowpea. The study shows that farmers have little or no knowledge regarding improved cowpea storage. They, therefore, did not perceive the pest infestation of their stored cowpea as a serious problem. Most of the farmers and traders involved in cowpea storage have limited access to credit facilities even though these facilities are panacea for them to acquire better storage facilities for their crops. The quantity of agro-chemicals used for cowpea storage by farmers and cowpea traders also impact positively on farmers and traders chances to adopt improved crib facilities for their cowpea storage.

Based on these findings, the study calls for the education of farmers and traders alike involved in cowpea storage. There is the need to educate farmers on the economic losses due to pests that attack their stored grains, especially 
cowpea. In these vein extension agents and other relevant agencies should be equipped to disseminate key cowpea storage pest control measures to farmers and traders of cowpea. As regards, the high cost of agro-chemicals and improved storage facilities, the study calls for subsides on the necessary cowpea storage agro-chemicals and other relevant facilities. This is more so for the improved storage facilities like the silos for grain storage. Such subsidy initiatives should be communicated to farmers and traders of grains who in turn can avail themselves of such initiatives.

\section{References}

Appert, J. 1987. The Storage of Food Grains and Seeds, Macmillan Publisher Ltd. London. Pp. 1-46

Ajibola, O. O. and A. M. Daramola. 1998. Development and management of storage structures for small and medium scale farmers. In National Stored Products Research Institute Bulletin. Pp. 103-105

Dike, M.C. 1994. An annotated check list and the identification of major storage pest in Nigeria. Samaru Miscellaneous Paper. P. 130

Dugje, I. Y, Dugje, L. O, . Ekeleme , F, Kamara , A. Y., and Ajeigbe, H. 2009. Farmers' Guide to Cowpea Production in West Africa. International Institute of Tropical Agriculture (IITA). Ibadan, Nigeria.

Food and Agricultural Organisation (FAO). 1981. The Prevention of losses in cured fish. FAO Fisheries Technical Paper. Pp. 219: 87

Food and Agriculture Organization, (FAO). 2006. Core Production Data, http://faostat.fao.org/ (accessed June 25, 2007).

Igbeka, A. and Olumeko, O. 1993. Grain Storage Structures Available in Nigeria. Macillan Press. Pp. 20-25.

Kumar, R and N.O. Okonronkwo. 1991. Effectiveness of plant oils on cereals in storage. Journal of Insect Science and its Application 12:77-85.

Musa, A. K. and J. F. Adetunji, 1999. Comparison of the efficacy of soya bean, groundnut and olive oil in the control of maize weevil. Centre Point Journal Science Edition 9: 91-100

Olumeko, O. 1989. Improved Storage facilities for Grains. Macmillan Press. Pp. 24-30.

Sharam, H. C. and K. F. Nwanze. 1997. Insect Pest of Sorghum: Biology, Extent of losses and Economic Threshed Plant Research (Eds). Pp. 9-23.

Singh, S. R., B. B. Singh, L. E. N. Jackai and B. R. 1997 Ntare. Advances in Cowpea Research. In International Institute of Tropical Agriculture (IITA) Bulletin, Ibadan, Nigeria. 